\title{
A Suitable Device for Cystic Lesions Close to the Tooth-Bearing Areas of the Jaws
}

\author{
Fábio Wildson Gurgel Costa, DDS, MSc, PhD, * \\ Francisco Samuel Rodrigues Carvalbo, DDS, $\dagger$ Filipe Nobre Chaves, DDS, $\ddagger$ \\ and Eduardo Costa Studart Soares, DDS, MSc, PbD $\S$
}

\begin{abstract}
Different devices for decompression of cystic lesions of the jaw have been described in the literature. Although there are no rigorous rules for choosing a particular design or method, the choice depends on situational needs. Although minor, most techniques are associated with certain difficulties and complications, such as the need for long-term monitoring, inappropriate decompression tube size, soft tissue trauma, suture dehiscence, soft tissue invagination, dislodgement, and malpositioning of the tube into the lesion. These complications may have a negative impact on the level of treatment acceptance, especially when devices are used over long periods. The aim of this study was to present a new suitable device for cystic lesions close to tooth-bearing areas of the jaws.
\end{abstract}

(C) 2014 American Association of Oral and Maxillofacial Surgeons

J Oral Maxillofac Surg 72:96-98, 2014

Decompression of odontogenic cystic lesions, a relatively simple and common procedure, may be performed as a definitive treatment modality or as an adjunct to other surgical techniques. ${ }^{1,2}$ The procedure decreases the lesion, facilitating subsequent enucleation, and lowers the risk of recurrence. ${ }^{2}$

Several devices have been used successfully for decompression, as described in the international literature. ${ }^{1-6}$ However, most techniques are associated with certain difficulties and complications, such as the need for long-term monitoring, inappropriate decompression tube size, soft tissue trauma, suture dehiscence, soft tissue invagination, dislodgement, and malpositioning of the tube into the lesion. ${ }^{3}$ Although minor, these complications have a negative impact on a patient's quality of life during treatment and on the level of treatment acceptance, especially when devices are used over long periods. ${ }^{1}$

Thus, the aim of this study was to present a new suitable decompression device for odontogenic cystic lesions close to tooth-bearing areas of the jaws.

\section{Technique}

Unlike previously described decompression devices, the device in the present design is attached with resin to the crown of a tooth adjacent to the area requiring decompression. Initially, a segment of polyethylene suction tube is prepared according to the radiographic size of the lesion. Using a disposable needle, a hole is drilled near the extremity, large enough to allow the passage of a $0.8-\mathrm{mm}$ orthodontic stainless steel wire. With the aid of a needle holder, one end of the wire is shaped into a loop and the other end is inserted through the hole in the tube, pulled back, and twisted (Figs 1, 2). Subsequently, the tooth crown is etched with acid and the loop is attached to the dental surface with composite resin (Fig 3). If necessary, the loop may be repositioned later for improved stability, control of surgical cavity depth, and adaptation to wound margins, thereby preventing adjacent soft tissue invagination into the lesion, which is a well-known postsurgical complication (Fig 4).
Received from the Federal University of Ceará, Fortaleza, Ceará, Brazil.

*Adjunct Professor, Division of Oral Radiology, School of Dentistry.

$\dagger$ Postgraduate Student, Division of Oral and Maxillofacial Surgery, Walter Cantídio University Hospital.

$\ddagger$ Postgraduate Student, Department of Clinical Dentistry, School of Dentistry.

$\S$ Full Professor, Division of Oral and Maxillofacial Surgery, Walter Cantídio University Hospital.
Address correspondence and reprint requests to Dr Carvalho: School of Dentistry, Federal University of Ceará, Rua Alexandre Baraúna, 949 Rodolfo Teófilo, CEP 60430-160, Fortaleza, Ceará, Brazil; e-mail: samuel.rcarvalho@gmail.com

Received July 92013

Accepted July 112013

(c) 2014 American Association of Oral and Maxillofacial Surgeons

0278-2391/13/00916-6\$36.00/0

http://dx.doi.org/10.1016/i.joms.2013.07.010 


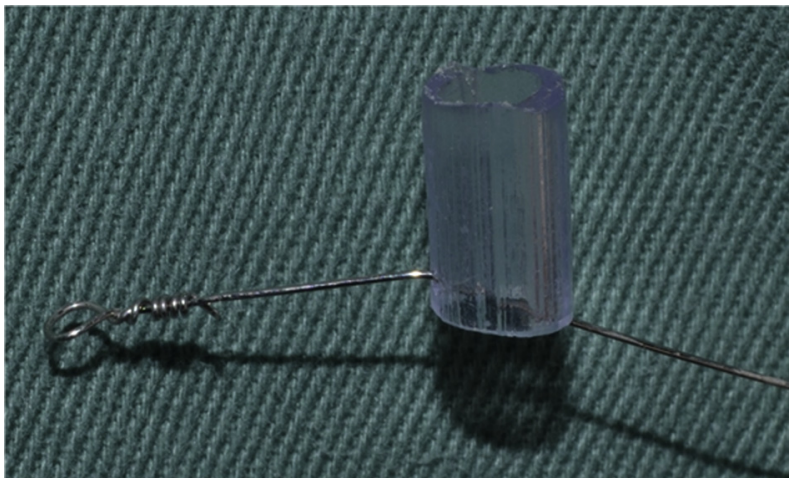

FIGURE 1. One end of the orthodontic stainless steel wire is shaped into a loop.

Costa et al. A New Device of Decompression. J Oral Maxillofac Surg 2014.

Because the device will be maintained for a long period, the patient is advised to perform careful intralesional hygiene 3 times a day with a disposable syringe containing a $0.12 \%$ chlorhexidine solution.

\section{Discussion}

Different devices for decompression of cystic lesions of the jaw and maintenance of the surgical window have been described in the literature (Table 1). Although there are no rigorous rules for choosing a particular design or method, the choice depends on situational needs. The devising described in the present report is suitable for cystic lesions close to toothbearing areas of the jaws.

Decompression devices have traditionally been attached to the surrounding soft tissue with sutures. ${ }^{1}$

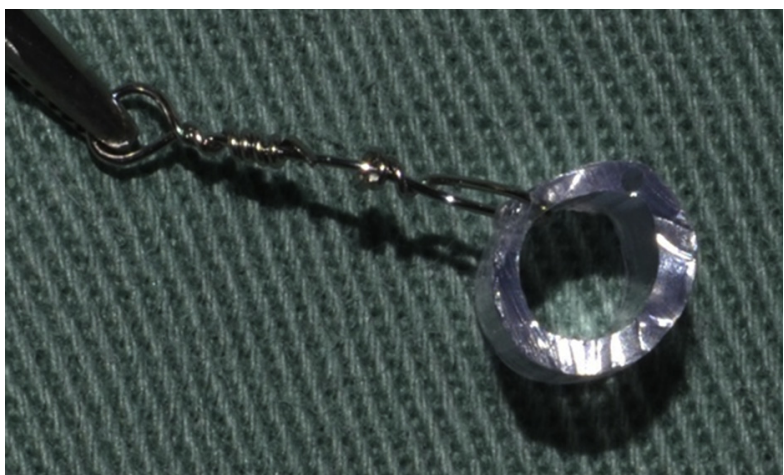

FIGURE 2. The other end of the orthodontic stainless steel wire is inserted through the hole in the tube, pulled back, and twisted.

Costa et al. A New Device of Decompression.J Oral Maxillofac Surg 2014 .

This fixation method provides insufficient stability in case of surgical wound dehiscence. Poor adjustment increases the likelihood of device-related complications mainly caused by micromovements. ${ }^{1,3}$ Thus, Kolokythas et al $^{1}$ attached the device to the cervical margin of the tooth using steel wire, whereas Swantek et $\mathrm{al}^{3}$ and Catunda et $\mathrm{al}^{6}$ used bone screws. However, although the former technique favors dental plaque buildup and periodontal injury from direct trauma, the latter is relatively costly and skill-intensive. As shown in this report, the attachment of the device to the crown of an adjacent tooth provides greater stability and minimizes the need for additional surgical interventions related to poor adjustment or invagination into the surgical cavity.

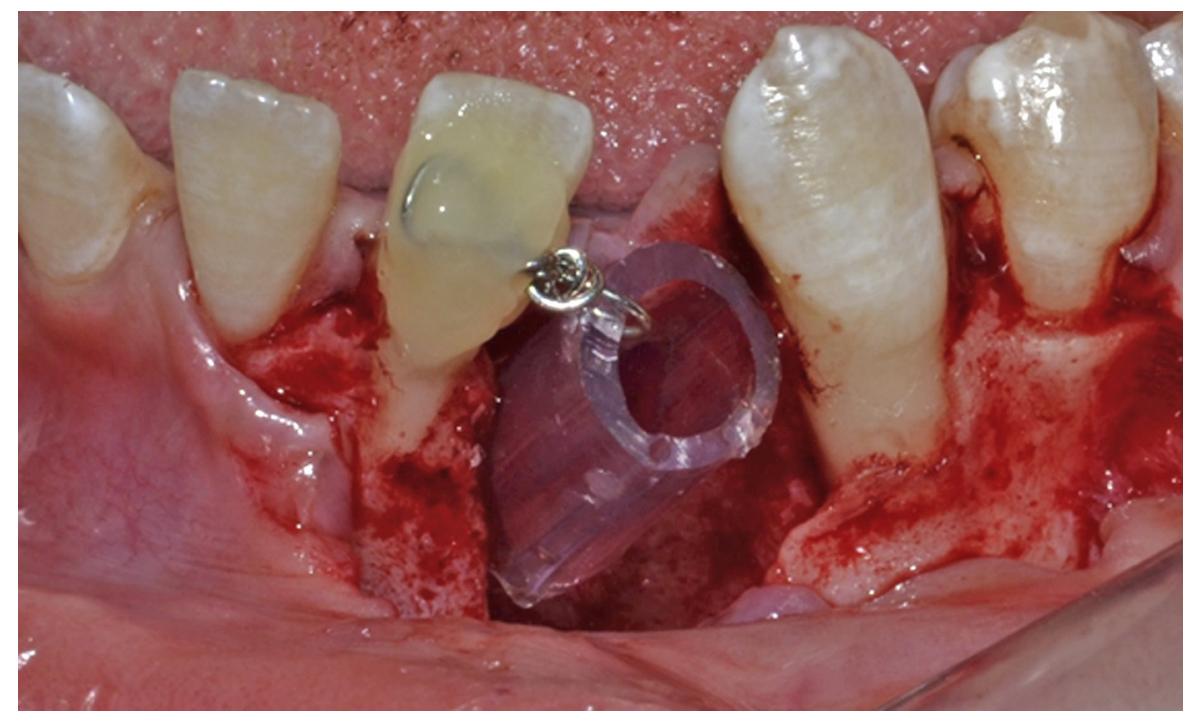

FIGURE 3. The loop is attached to the acid-etched dental surface with composite resin. 


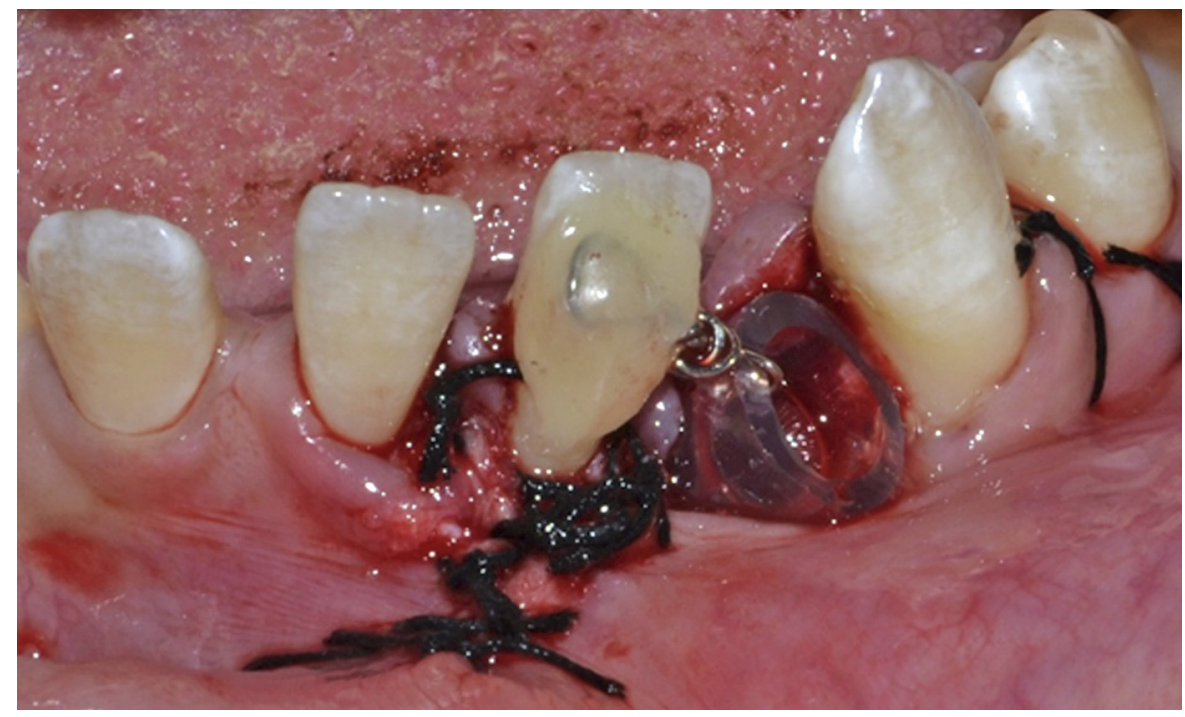

FIGURE 4. The loop may be repositioned later for improved stability, control of surgical cavity depth, and adaptation to wound margins. Costa et al. A New Device of Decompression. J Oral Maxillofac Surg 2014.

Table 1. DECOMPRESSION DEVICES DESCRIBED IN THE INTERNATIONAL LITERATURE

\begin{tabular}{|c|c|c|c|c|}
\hline Reference & Material & Fixation Method & Tissue & Minor Limiting Factor \\
\hline Enislidis et al, ${ }^{5} 2004$ & $\begin{array}{l}\text { shortened } \\
\text { polyethylene tubes }\end{array}$ & suture & mucosa & $\begin{array}{l}\text { micromovements and } \\
\text { device displacement }\end{array}$ \\
\hline Pogrel and Jordan, ${ }^{2} 2004$ & $\begin{array}{l}\text { shortened } \\
\text { nasopharyngeal } \\
\text { tube }\end{array}$ & suture & mucosa & $\begin{array}{l}\text { micromovements and } \\
\text { device displacement }\end{array}$ \\
\hline Tolstunov, ${ }^{4} 2008$ & $\begin{array}{l}\text { shortened nasal } \\
\text { oxygen cannulas }\end{array}$ & suture & mucosa & $\begin{array}{l}\text { micromovements and } \\
\text { device displacement }\end{array}$ \\
\hline Kolokythas et al, ${ }^{1} 2011$ & $\begin{array}{l}\text { polyethylene } \\
\text { intravenous tube }\end{array}$ & ligature wire & $\begin{array}{l}\text { teeth (at level of } \\
\text { mucogingival } \\
\text { junction) }\end{array}$ & periodontal trauma \\
\hline Swantek et al, ${ }^{3} 2012$ & $\begin{array}{l}\text { suction tubing plastic } \\
\text { connector }\end{array}$ & 2 screws, $1.2-\mathrm{mm}$ suture & bone, mucosa & $\begin{array}{l}\text { special microscrews } \\
\text { and screwdrivers }\end{array}$ \\
\hline Catunda et $\mathrm{al}^{6}{ }^{6} 2013$ & Luer syringe & $\begin{array}{l}2 \text { self-tapping screws, } \\
1.2 \text { - or } 1.5-\mathrm{mm} \text { suture }\end{array}$ & bone, mucosa & $\begin{array}{l}\text { special microscrews } \\
\text { and screwdrivers }\end{array}$ \\
\hline
\end{tabular}

Costa et al. A New Device of Decompression. J Oral Maxillofac Surg 2014.

According to Tolstunov, ${ }^{4}$ the following characteristics are ideal for decompression devices: 1) have a design that prevents the device from falling into the bone cavity or coming out from the cavity at the end of the procedure, 2) be small enough and not interfere with daily mastication, 3) be fixated easily to the surrounding soft tissue, 4) provide easy daily cleaning of the cystic cavity through its opening by the patient or staff, and 5) be hygienic and not accumulate food particles while in use. Thus, the authors believe that the present device is a simple method that matches all the requirements of a decompression device, thus avoiding an increased risk of postoperative morbidity and the need for new surgical procedures.

\section{References}

1. Kolokythas A, Schlieve T, Miloro M: Simple method for securing a decompression tube for odontogenic cysts and tumors: A technical note. J Oral Maxillofac Surg 69:2392, 2011

2. Pogrel MA, Jordan RC: Marsupialization as a definitive treatment for the odontogenic keratocyst. J Oral Maxillofac Surg 62:651, 2004

3. Swantek JJ, Reyes MI, Grannum RI, et al: A technique for long term decompression of large mandibular cysts. J Oral Maxillofac Surg 70:856, 2012

4. Tolstunov L: Marsupialization catheter. J Oral Maxillofac Surg 66: 1077,2008

5. Enislidis G, Fock N, Sulzbacher I, et al: Conservative treatment of large cystic lesions of the mandible: A prospective study of the effect of decompression. Br J Oral Maxillofac Surg 42:546, 2004

6. Catunda IS, Catunda RB, Vasconcelos BC, et al: Decompression device for cavitary bone lesions using Luer syringe. J Oral Maxillofac Surg 71:723, 2012 